\title{
Soil-Saprolite Profiles Derived from Mafic Rocks in the North Carolina Piedmont: I. Chemical, Morphological, and Mineralogical Characteristics and Transformations ${ }^{1}$
}

\author{
T. J. RICE, JR., S. W. BUOL, AND S. B. WEED ${ }^{2}$
}

\begin{abstract}
The chemical, morphological and mineralogical properties of two Enon sandy loam (fine, mixed, thermic Ultic Hapludalfs) soilsaprolite profiles, one formed on gabbro and the other on metagabbro, are compared. Clay skins are scarce and stress cutans common in the argillic horizons of these soils. Iron-manganese concretions are concentrated in soil horizons immediately above the argillic horizons. The high shrink-swell capacities and slow permeabilities of the argillic horizons result in relatively shallow depths to paralithic contact with saprolite. The parent rock from the Enon profile near Albemarle, Stanly County, North Carolina is a medium-grained metagabbro with chlorite, hornblende, quartz, and calcic plagioclase feldspar as the dominant primary minerals. Chlorite weathers to regularly interstratified chlorite-vermiculite, which alters to randomly interstratified chlorite-vermiculite and smectite. Particle size decreases with each mineral alteration. Hornblende weathers to smectite and goethite. Calcic plagioclase feldspar transforms to kaolinite in the saprolite and soil horizons. Quartz is relatively resistant to chemical weathering. The parent rock of the Enon profile

${ }^{1}$ Paper no. 9108 of the North Carolina Research Journal Series Service, Raleigh, NC 27650. Presented before Div. S-9, Soil Sci. Soc. of Am., Detroit, MI, 2 Dec. 1980. Received 23 Feb. 1984. Approved 11 Aug. 1984.

${ }_{2}^{2}$ Former Graduate Research Assistant and Professors of Soil Science, respectively, Dep. Soil Science, North Carolina State Univ. Raleigh, NC 27650. The senior author is now Assistant Professor, Soil Science Dep., Calif. Polytechnic State Univ., San Luis Obispo, CA 93407 .
\end{abstract}

near Concord, Cabarrus County, North Carolina is a coarse-grained gabbro with hornblende and calcic plagioclase feldspar as the dominant primary minerals. Hornblende transforms to smectite and goethite. Calcic plagioclase feldspar alters to kaolinite in the saprolite and soil horizons.

Additional Index Words: weathering, gabbro, Alfisols, argillic horizon, mineralogy.

Rice, Jr., T.J., S.W. Buol, and S.B. Weed. 1985. Soil-saprolite profiles derived from mafic rocks in the North Carolina piedmont: I. Chemical, morphological, and mineralogical characteristics and transformations. Soil Sci. Soc. Am. J. 49:171-178.

$\mathrm{T}$ HE TERM "mafic" (or basic) is used to describe subsilicic igneous rocks composed mainly of minerals with high contents of magnesium $(\mathrm{Mg})$ and iron $(\mathrm{Fe})$, the ferromagnesian minerals. Ferromagnesian is applied to certain dark-colored silicate minerals, especially amphiboles, pyroxenes, biotite, and olivine (American Geological Institute, 1976). Common mafic rocks are basalt (fine-grained), dolerite (diabase; medium-grained), gabbro (coarse-grained) and metamorphic derivatives from them. They are nearly the same in general mineralogical composition but vary in mineral grain size. 
The predominant ferromagnesian primary minerals in gabbro and metagabbro are pyroxenes, olivines, chlorite and biotite (Basham, 1974; Wilson and Farmer, 1970; Craig and Loughnan, 1964; Glentworth, 1944; DeConinck et al., 1977; Wilson, 1966, 1970). The secondary weathering products of biotite are vermiculite, hydrobiotite, or kaolinite (Basham, 1974; Wilson, 1966). A detailed study of hornblende weathering by Wilson and Farmer (1970) showed hornblende, with discrete interlamellar intergrowths of another amphibole, to alter to interstratified swelling chlorite-smectite that later transformed to smectite and kaolinite closer to the soil surface. Smectite, iron oxides and hydroxides, and kaolinite are common secondary weathering products of amphiboles, pyroxenes, and olivine (Basham, 1974; Butler, 1953). "Green rocks" (metagabbro) from Lower Zaire contained chloritized actinolite that weathered to regular mixedlayer chlorite-vermiculite which in turn weathered to smectite and kaolinite with increased leaching of $\mathrm{Ca}^{2+}$ and $\mathrm{Mg}^{2+}$ (DeConinck et al., 1977).

Plagioclase feldspars are also important primary minerals in gabbro (Glentworth, 1944). The secondary weathering products of plagioclase feldspars are kaolinite (Butler, 1953), halloysite (Cady, 1950), and montmorillonite (Eswaran, 1979). Nyun and McCaleb (1955) reported that in North Carolina soils the order of increasing resistance to weathering is: ferromagnesian minerals, feldspars, biotite, quartz. Basham (1974) found that pyroxenes and biotite are readily altered but feldspars and hornblende are largely unaffected.

North Carolina Piedmont soils derived from mafic (basic) crystalline rocks and mixed mafic and felsic (acid) crystalline rocks were formerly classified mainly as Planosols (Lee, 1955). Presently, these soils are classified mainly as subgroups of Hapludalfs while the soils over felsic crystalline rock are Hapludults (Soil Survey Staff, 1975).

This study was undertaken to better understand the pedogenesis of Alfisols formed from residual mafic rock and to determine the vertical pattern of mineral alteration in the saprolite and solum of two profiles, one formed from coarse-grained and one from fine-grained mafic rock. Both soils are classified as Enon sandy loam (fine, mixed, thermic Ultic Hapludalfs).

\section{MATERIALS AND METHODS}

One profile is in Stanly County, North Carolina and developed on metagabbro. The second profile is in Cabarrus County, North Carolina and developed from gabbro.

The maximum depth of the sampling pit depth was determined by the resistance of the saprolite to further backhoe penetration. Soil and saprolite samples were collected from each indentifiable horizon. Bulk, air-dried soil and saprolite samples from each horizon were passed through a $2 \times 10^{-3} \mathrm{~m}$ sieve.

Soil pH values, bulk density, extractable acidity, exchangeable bases, particle size and organic carbon were determined by standard procedures (Peech et al, 1962; Soil Conservation Service, 1972; Kilmer and Alexander, 1949).

Rock, saprolite, and soil thin sections were prepared by impregnation with a mixture of Castolite resin $\left(300 \times 10^{-3} \mathrm{~L}\right)$, methyl methacrylate $\left(200 \times 10^{-2} \mathrm{~L}\right)$, and benzoyl peroxide (3 g) (Buol and Fadness, 1961).

Clay samples used for cation exchange capacity (CEC) and surface area analyses were fractionated into fine $(<0.2 \times$ $\left.10^{-6} \mathrm{~m}\right)$ and coarse $\left(2-0.2 \times 10^{-6} \mathrm{~m}\right)$ clay sized components (Jackson, 1975). Soil subsamples from each horizon were treated with pH 5.0, $1 \mathrm{M} \mathrm{NaOAc}$ solution (Jackson, 1975) and with sodium hypochlorite (Clorox) for organic matter oxidation (Anderson, 1963) prior to fractionation.

External (nonexpanded) surface area of the nondeferrated clays was determined by nitrogen gas adsorption using a Quantachrome Quantasorb Surface Area Analyzer. ${ }^{3}$ Total surface area of the nondeferrated clays was determined by adsorption of ethylene glycol monoethyl ether (EGME) (Carter et al, 1965). Cation exchange capacity (CEC) of clays was measured by $\mathrm{CaCl}_{2}$ saturation and displacement by $\mathrm{Mg}\left(\mathrm{NO}_{3}\right)_{2}$ (Jackson, 1975).

Clay samples used for XRD were obtained from subsamples that were treated for organic matter oxidation (Anderson, 1963) and iron oxide removal (Jackson, 1975). Both fine and coarse clay fractions were dialyzed against distilled water and lyophilized (Malcolm, 1968). Potassium- and Mgsaturated clay and medium silt fractions were smeared as pastes on $25 \times 7510^{-3} \mathrm{~m}$ glass microscope slides (Jackson, 1975) for XRD analysis. The deferrated fine sand was handground in $100 \%$ ethanol for about $10 \mathrm{~min}$ in an agate mortar and pestle, $\mathrm{Mg}$-saturated, smeared on a glass slide, and $\mathrm{x}$ rayed at room temperature. Kaolinite content was determined quantitatively by differential thermal analysis (DTA).

\section{RESULTS AND DISCUSSION}

\section{Profile Genesis and Morphology}

\section{Enon (Metagabbro) Profile}

Immediately below a $3 \times 10^{-2} \mathrm{~m}$ Oa horizon, the A horizon has iron-manganese concretions of both irregular and spherical shape. Some of the concretions appear to be aggregates of small quartz, hornblende, and feldspar grains cemented by the Fe-Mn oxides. Many concretions are dark-colored at the core and redder on the rim suggesting higher $\mathrm{Mn}$ contents at the center typical of other Fe-Mn concretions found in similar Iredell soils (Gallaher et al., 1973). Coarse fragment content increases in the $\mathrm{E}$ and $\mathrm{BA}$ horizons (Table 1). A thin platy layer (less than $5 \times 10^{-2} \mathrm{~m}$

\footnotetext{
${ }^{3}$ The use of trade names in this publication does not imply endorsement by the North Carolina Agricultural Research Service of
} the products named, or criticism of similar ones not mentioned.

Table 1. Physical characteristics of Enon profiles.

\begin{tabular}{|c|c|c|c|c|c|c|c|c|c|}
\hline $\begin{array}{l}\text { Hori- } \\
\text { zon }\end{array}$ & Depth & Color & $\begin{array}{l}\text { Struc. } \\
\text { ture } †\end{array}$ & $\begin{array}{l}>2 \times \\
10^{-3}\end{array}$ & Sand & Silt & $\begin{array}{c}\text { Coarse } \\
\text { clay }\end{array}$ & $\begin{array}{l}\text { Fine } \\
\text { clay }\end{array}$ & $\begin{array}{c}\text { Bulk } \\
\text { density }\end{array}$ \\
\hline \multicolumn{3}{|c|}{$10^{-2} \mathrm{~m}$} & & & & 8 & & & $-\mathrm{Mg} \mathrm{m}^{-1}$ \\
\hline \multicolumn{10}{|c|}{ Enon (metagabbro) profile } \\
\hline A & $0-10$ & 10YR $3 / 2$ & $\mathbf{w}, \mathbf{f}, \mathbf{s b k}$ & 3.3 & 47.1 & 49.9 & 2.3 & 0.7 & 1.35 \\
\hline $\mathbf{E}$ & $10-20$ & $2.5 Y 5 / 3$ & $\mathrm{~m}, \mathrm{f}, \mathrm{sbk}$ & 9.9 & 48.7 & 44.2 & 0.4 & 6.7 & 1.87 \\
\hline $\mathrm{BE}$ & $20-33$ & 10 YR $5 / 6$ & $\mathrm{~m}, \mathrm{~m}, \mathbf{s b k}$ & 8.3 & 38.6 & 43.9 & 7.3 & 10.4 & 1.75 \\
\hline Bt1 & $33-51$ & 10 YR $5 / 6$ & $\mathrm{~m}, \mathrm{vc}, \mathrm{pr}$ & 0.6 & 8.4 & 18.4 & 25.3 & 47.9 & \\
\hline Bt2 & $51-71$ & $10 Y R 5 / 6$ & $\mathbf{m}, \mathbf{v c}, \mathrm{pr}$ & 0 & 28.7 & 39.9 & 1.2 & 30.3 & 1.96 \\
\hline BC & $71-81$ & $10 Y R 5 / 4$ & $\mathbf{m}, \mathbf{m}, \mathbf{s b k}$ & 0 & 26.0 & 56.1 & 3.1 & 14.1 & 1.95 \\
\hline $\mathrm{Cr} 1$ & $81-114$ & 10 YR $5 / 3$ & $\mathrm{RC}$ & 0 & 37.3 & 52.8 & 1.1 & 1.8 & 2.06 \\
\hline $\mathrm{Cr} 2$ & $114-147$ & 10 YR $5 / 3$ & $\mathrm{RC}$ & 0 & 51.2 & 43.8 & 3.7 & 1.4 & 2.10 \\
\hline $\mathrm{Cr} 3$ & $147-188$ & 10 YR $5 / 3$ & $\mathrm{RC}$ & 0 & 59.3 & 37.0 & 2.6 & 1.2 & 2.18 \\
\hline \multicolumn{10}{|c|}{ Enon (gabbro) profile } \\
\hline Ap & $6-18$ & $7.5 Y R 3 / 4$ & $\mathrm{~m}, \mathrm{f}, \mathrm{sbk}$ & 1.9 & 63.2 & 19.4 & 6.0 & 11.1 & 2.06 \\
\hline $\mathrm{Bt}$ & $18-43$ & $7.4 Y R 4 / 6$ & w, vc, pr & 0 & 33.0 & 24.1 & & 36.8 & 2.01 \\
\hline BC & $43-64$ & 7.5 YR 4/6 & w, c, sbk & 0 & 62.0 & 15.1 & 6.2 & 17.0 & 1.99 \\
\hline C & $64-86$ & $10 \mathrm{YR} 3 / 4$ & $\mathrm{ma}$ & 0 & 90.1 & 7.2 & 0.3 & 2.5 & 2.08 \\
\hline Cr1 & $86-135$ & $10 \mathrm{YR} 2 / 2$ & $\mathrm{RC}$ & 0 & 89.7 & 7.4 & 1.7 & 1.4 & 2.57 \\
\hline Cr2 & $135-165$ & $10 \mathrm{YR} 2 / 2$ & $\mathrm{RC}$ & 0 & 93.6 & 5.4 & 0.6 & 0.5 & 2.61 \\
\hline Cr3 & $154-203$ & $10 \mathrm{YR} 2 / 2$ & $\mathrm{RC}$ & 0 & 92.4 & 5.7 & 1.1 & 1.0 & 2.63 \\
\hline
\end{tabular}

† Structure: Grade $-\mathrm{m}=$ moderate, $w=$ weak; Class $-\mathrm{vc}=$ very coarse, $\mathrm{c}=$ coarse, $m=$ medium, $f=$ fine; Type - sbk = subangular blocky, $\mathrm{pr}=$ prismatic, $\mathrm{ma}=$ massive, $\mathrm{RC}=$ rock controlled. 
thick) composed of $60 \%$ (by volume) concretions is found immediately above the Bt1 horizon.

The concretions and platy structure suggest a very slowly permeable argillic horizon that "perches" water after heavy rainstorms (McCracken et al., 1964). Alternate wetting and drying cycles combined with a higher organic matter content and attendant microbial activity cause alternating oxidation-reduction conditions favoring the formation of Fe-Mn concretions (Marshall, 1977).

The clay content increase in the Bt1 and Bt2 horizons is diagnostic for an argillic horizon (Soil Survey Staff, 1975). Even though thin clay skins are described in the field and the content of fine clay shows a significant increase (Table 1), few features indicative of optically oriented translocated clay were found in thin section analysis. The combination of high clay content and expansible clay minerals has resulted in expansion and contraction causing clay skin destruction (Buol and Hole, 1961; Nettleton et al, 1969). Cracks up to $10^{-4} \mathrm{~m}$ wide were observed to separate very coarse prismatic structural peds and stress cutans were evident on adjoining peds in the argillic horizon during sampling.

A thin $\left(10^{-3} \mathrm{~m}\right) \mathrm{BC}$ horizon occurs above the paralithic contact with saprolite. The saprolite is recognized as rock-controlled structure with dark-colored Fe-Mn oxide stains on the fracture faces. Saprolite fractures intersecting the argillic horizon are filled with some translocated clay. Minerals within the saprolite mass show evidences of weathering like dark red ( $\mathrm{Fe})$ and black (Mn) stains along edges of ferromagnesian minerals. The translocated clay and primary mineral staining suggest that some solution is able to leach below the argillic horizon. Presumably, most leaching occurs along the major cracks in the argillic horizon with the first wetting after a period of dryness and along the larger saprolite fractures.

Low-grade metamorphism changed the original gabbro to a metagabbro of the greenschist facies. Reaction of original hornblende has resulted in the crystallization of metamorphic actinolite, chlorite, and quartz. The original calcic plagioclase feldspar was partially changed to epidote and quartz. The green color of the rock is indicative of the crystallization of metamorphic chlorite, epidote, and/or actinolite (Table 3). The high silt content in the saprolite and soil horizons (Table 1 ) is thought to be caused by recrystallization during metamorphism.

\section{Enon (Gabbro) Profile}

Although chemically similar to the metagabbro profile (Table 2), this soil has been under cultivation for over one hundred yr. Compaction of the epipedon (AP) and a high content of ferromagnesian minerals both contribute to a high bulk density (Table 1). The Ap horizon contains common sand-sized hornblende, calcic plagioclase feldspar, and quartz. The quartz is derived from dikes that dissect the gabbro country rock. Quartz gravels were found on the soil surface at the time of sampling but were absent in the gabbro parent rock (Table 3). Large Fe-Mn concretions and quartz gravels account for the $1.9 \%$ coarse fragments in this horizon. The presence of Fe-Mn concretions suggest a seasonally perched water table and impeded internal drainage (Marshall, 1977).

Clay content decreases in the $\mathrm{BC}$ horizon. A paralithic contact occurs at the base of the $\mathrm{C}$ horizon. This horizon has a sand texture (Table 1), but contains several cracks which are often coated with well-

Table 2. Modal analysis of parent rock thin sections.

\begin{tabular}{lcc}
\hline Mineral & Metagabbro & Gabbro \\
\hline & & $\%$ \\
\cline { 2 - 3 } Biotite & 2 & \\
Chlorite & 39 & 3 \\
Hornblende & 13 & - \\
Plagioclase & 20 & 27 \\
Quartz & 6 & 50 \\
Other ferromagnesian $\dagger$ & 17 & - \\
Opaqueł & 3 & 15 \\
\hline
\end{tabular}

$\dagger$ Actinolite, augite, epidote, ferrohypersthene, or olivine.

$\ddagger$ Ilmenite, magnetite.

Table 3. Chemical characteristics of Enon profiles based on untreated whole soil.

\begin{tabular}{|c|c|c|c|c|c|c|c|c|c|c|c|c|}
\hline \multirow[b]{2}{*}{ Horizon } & \multirow[b]{2}{*}{ Depth } & \multicolumn{2}{|c|}{$\mathrm{pH}$} & \multirow{2}{*}{$\underset{\mathrm{C}}{\text { Organic }}$} & \multicolumn{4}{|c|}{ Exchangeable bases $†$} & \multirow{2}{*}{$\begin{array}{l}\text { Sum of } \\
\text { bases }\end{array}$} & \multirow{2}{*}{$\begin{array}{c}\text { Extractable } \\
\text { acidity }\end{array}$} & \multirow{2}{*}{$\begin{array}{c}\text { CEC } \\
\text { (pH 8.2) }\end{array}$} & \multirow{2}{*}{$\begin{array}{c}\text { Base } \\
\text { saturation }\end{array}$} \\
\hline & & $\mathrm{H}_{2} \mathrm{O}$ & $\mathrm{KCl}$ & & $\mathbf{C a}$ & $\mathbf{M g}$ & $\mathbf{N a}$ & $\mathbf{K}$ & & & & \\
\hline & $10^{-2} \mathrm{~m}$ & & & $\mathbf{g} \mathbf{~ k g}^{-1}$ & $\ldots$ & & & $2011+$ & & & & $\%$ \\
\hline \multicolumn{13}{|c|}{ Enon (metagabbro) profile } \\
\hline $\mathbf{A}$ & $0-10$ & 5.0 & 4.3 & 41 & 6.3 & 1.6 & 0.1 & 0.2 & 8.1 & 21.2 & 29.3 & 27.6 \\
\hline $\mathrm{E}$ & $10-20$ & 6.0 & 4.8 & 7 & 3.8 & 1.6 & $\mathrm{t}$ & $\mathrm{t}$ & 5.5 & 10.9 & 16.4 & 33.5 \\
\hline BE & $20-33$ & 5.6 & 4.3 & 5 & 4.2 & 2.4 & 0.1 & $\mathrm{t}$ & 6.7 & 17.3 & 24.0 & 27.9 \\
\hline Bt1 & $33-51$ & 5.6 & 3.9 & 7 & 7.8 & 2.6 & 0.3 & $\mathrm{t}$ & 10.7 & 21.8 & 32.5 & 32.9 \\
\hline Bt2 & $51-71$ & 5.6 & 4.0 & 5 & 9.2 & 2.6 & 0.5 & $\mathrm{t}$ & 12.2 & 18.6 & 30.8 & 39.6 \\
\hline $\mathrm{BC}$ & $71-81$ & 6.5 & 3.5 & 3 & 9.4 & 2.6 & 0.7 & $\mathrm{t}$ & 12.7 & 14.8 & 27.5 & 46.2 \\
\hline Cr1 & $81-114$ & 6.6 & 3.6 & 1 & 9.1 & 2.6 & 0.9 & $\mathrm{t}$ & 12.6 & 16.1 & 28.7 & 43.9 \\
\hline $\mathrm{Cr} 2$ & $114-147$ & 6.7 & 4.1 & 1 & 9.0 & 2.6 & 1.2 & $t$ & 12.8 & 15.9 & 28.7 & 44.6 \\
\hline $\mathrm{Cr} 3$ & $147-188$ & 6.7 & 4.2 & 1 & 9.1 & 2.6 & 1.5 & $\mathrm{t}$ & 13.2 & 14.8 & 28.0 & 47.1 \\
\hline \multicolumn{13}{|c|}{ Enon (gabbro) profile } \\
\hline Ap & $0-18$ & 6.2 & 5.0 & 9 & 5.6 & 2.3 & 0.1 & 0.3 & 8.3 & 15.4 & 23.7 & 35.2 \\
\hline $\mathrm{Bt}$ & $18-43$ & 6.1 . & 5.0 & 4 & 8.8 & 2.5 & 0.3 & $\mathrm{t}$ & 11.6 & 18.6 & 30.2 & 38.4 \\
\hline BC & $43-64$ & 6.2 & 4.8 & 4 & 7.5 & 2.5 & 0.2 & $\mathrm{t}$ & 10.2 & 11.6 & 21.8 & 46.8 \\
\hline $\mathrm{C}$ & $64-86$ & 6.5 & 5.1 & 2 & 4.0 & 3.4 & 0.1 & $\mathrm{t}$ & 7.5 & 12.1 & 19.6 & 38.3 \\
\hline Cr1 & $86-135$ & 6.6 & 4.7 & 1 & 3.9 & 1.9 & 0.1 & $\mathrm{t}$ & 5.9 & 9.6 & 15.5 & 38.1 \\
\hline $\mathrm{Cr} 2$ & $135-165$ & 6.6 & 4.7 & 2 & 3.0 & 1.6 & 0.1 & $\mathrm{t}$ & 4.7 & 9.0 & 13.7 & 34.3 \\
\hline $\mathrm{Cr} 3$ & $165-203$ & 6.8 & 5.1 & 1 & 2.7 & 1.6 & 0.1 & $\mathrm{t}$ & 4.4 & 8.8 & 13.2 & 33.2 \\
\hline
\end{tabular}

$\dagger \mathrm{t}=\operatorname{trace}(<0.1 \%)$. 


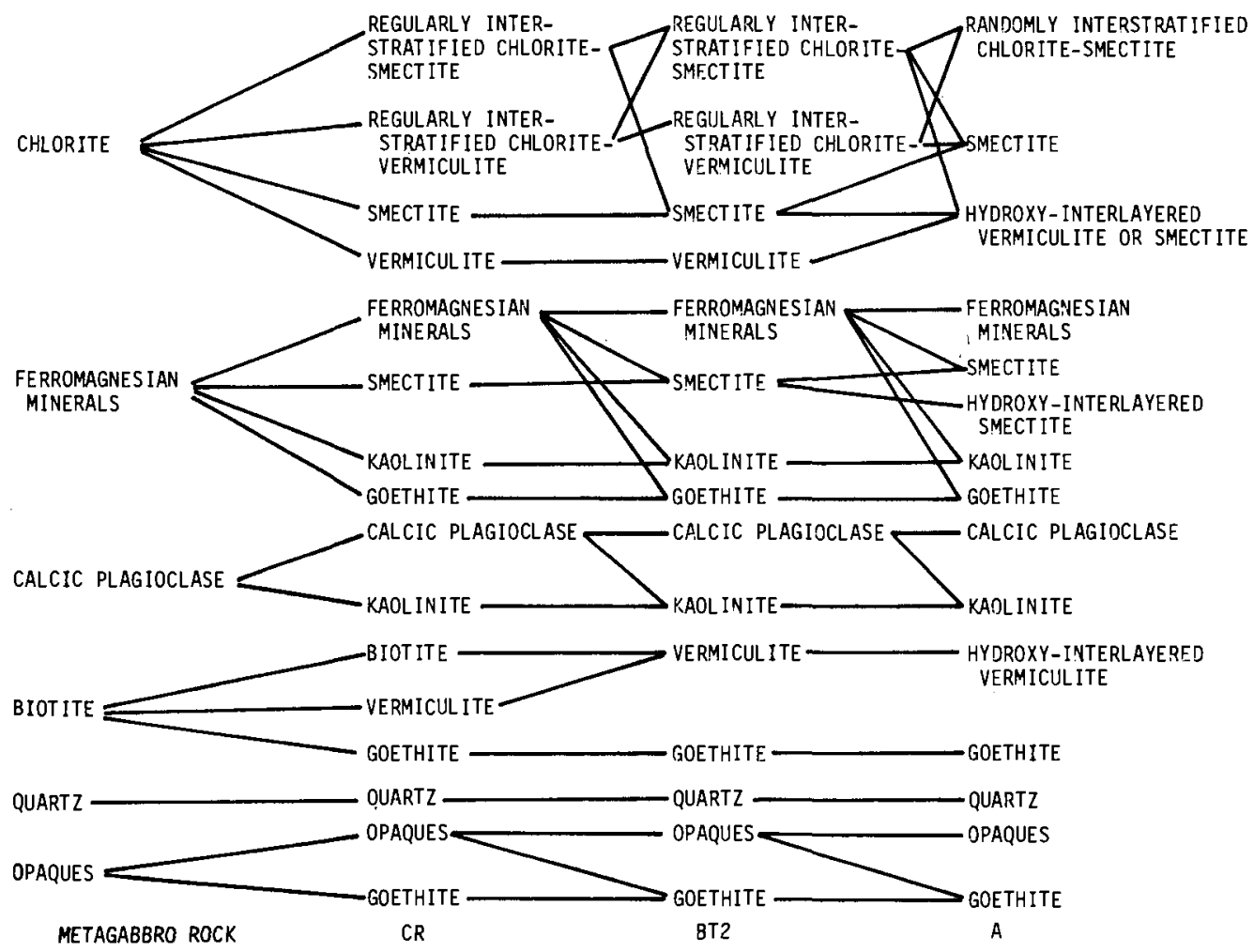

Fig. 1.-Proposed mineral transformations in Enon (metagabbro) soil-saprolite profile.

oriented clay skins notably lacking in the finer textured argillic horizon. The relatively shallow depth $(86$ $\times 10^{-2} \mathrm{~m}$ ) to the paralithic contact is thought to be due, in large part, to the slowly permeable argillic horizon which limits deep water percolation necessary for leaching and consequent mineral weathering.

The saprolite has a massive rock-controlled structure and a random network of fractures containing weathered in situ and translocated clay. Weathering rinds up to $2 \times 10^{-2} \mathrm{~m}$ thick are evident along the fractures and grade to relatively unweathered gabbro rock between fractures. The high sand and low silt and clay contents in the saprolite (Table 1) are a reflection of the coarse-grained texture of the original parent rock and limited weathering.

\section{Mineral Transformations in the Enon (metagabbro) Profile}

A flow diagram (Fig. 1) showing proposed mineral transformations and the relationships among primary minerals and their secondary weathering products was constructed using XRD and DTA data. Mineral compositions of various particle size fractions from the metagabbro profile (Table 4) allow several conclusions concerning weathering of primary and secondary minerals in this metagabbro profile:

1) Chlorite is not present in any soil or saprolite horizons (Fig. 3 and 4) and therefore must alter in deep saprolite horizons to regularly interstratified chlorite-vermiculite. Regularly interstratified chloritevermiculite transforms to randomly interstratified

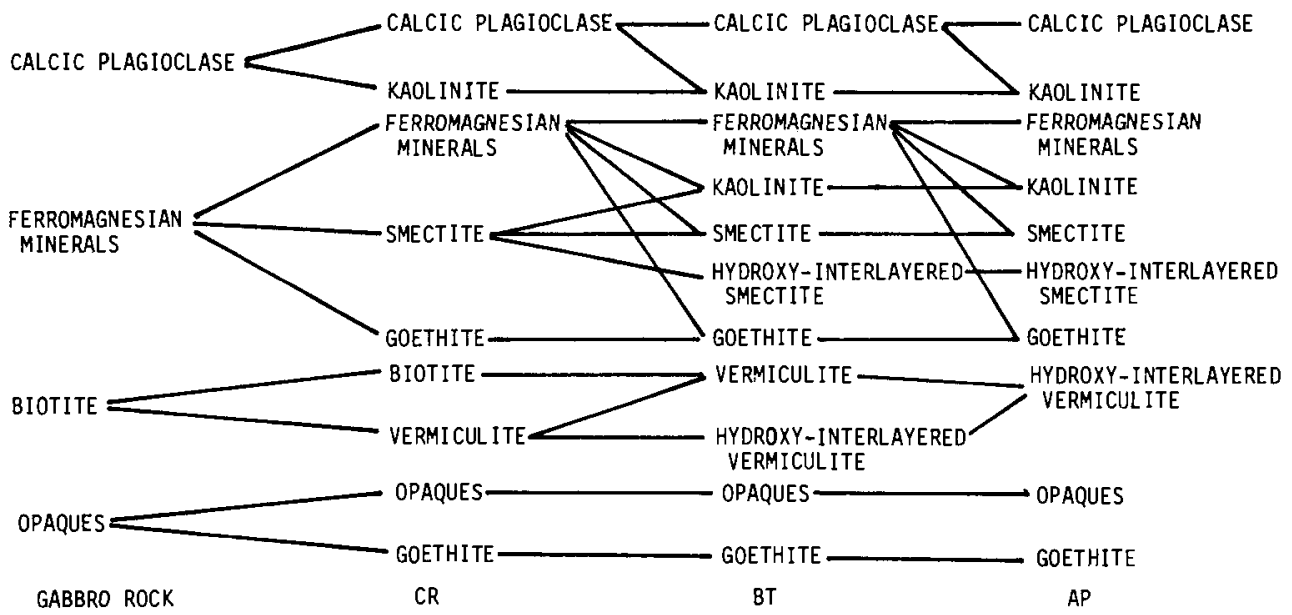

Fig. 2.-Proposed mineral transformations in Enon (gabbro) soil-saprolite profile. 
RICE ET AL.: SOIL-SAPROLITE PROFILES DERIVED FROM MAFIC ROCKS IN THE NORTH CAROLINA PIEDMONT: I. 175

Table 4. Mineral compositions of various particle size fractions of Enon soil-saprolite profiles as determined by $x$-ray diffraction and DTA. $\dagger$

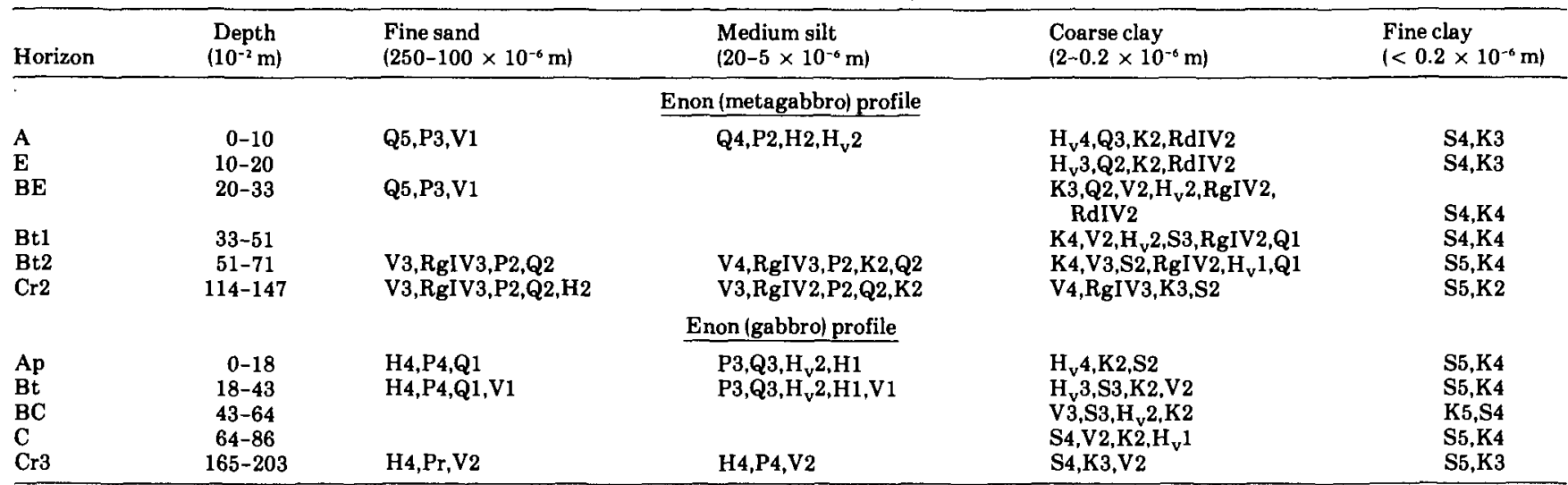

$\dagger \mathrm{H}=$ hornblende, $\mathrm{H}_{\mathbf{v}}=$ hydroxy-interlayered vermiculite or smectite, $\mathrm{K}=$ kaolinite, $\mathrm{P}=$ calcic plagioclase fledspar, $\mathrm{Q}=$ quartz, $\mathrm{RgIV}=$ regularly interstratified chlorite-vermiculite, $\mathrm{S}=$ smectite, $\mathrm{V}=$ vermiculite, $\mathrm{RdIV}=$ randomly interstratified chlorite-vermiculite. Approximate weight fraction: $5=$ more than half, $4=$ half to one-third, $3=$ one-third to one-fifth, $2=$ one-fifth to one-twentieth, $1=$ less than one-twentieth.

chlorite-vermiculite, vermiculite, and smectite with increasing proximity to the soil surface. It was not clear from this study whether some interstratified chlorite-smecite was present. Formation of regularly interstratified chlorite-vermiculite minerals in soils appears to result from the removal of the hydroxide sheet from alternate layers of chlorite during weathering (Johnson, 1964). Several workers have suggested that in pedogenic weathering, oxidation of ferrous iron plays a major role in the initiation of the structural
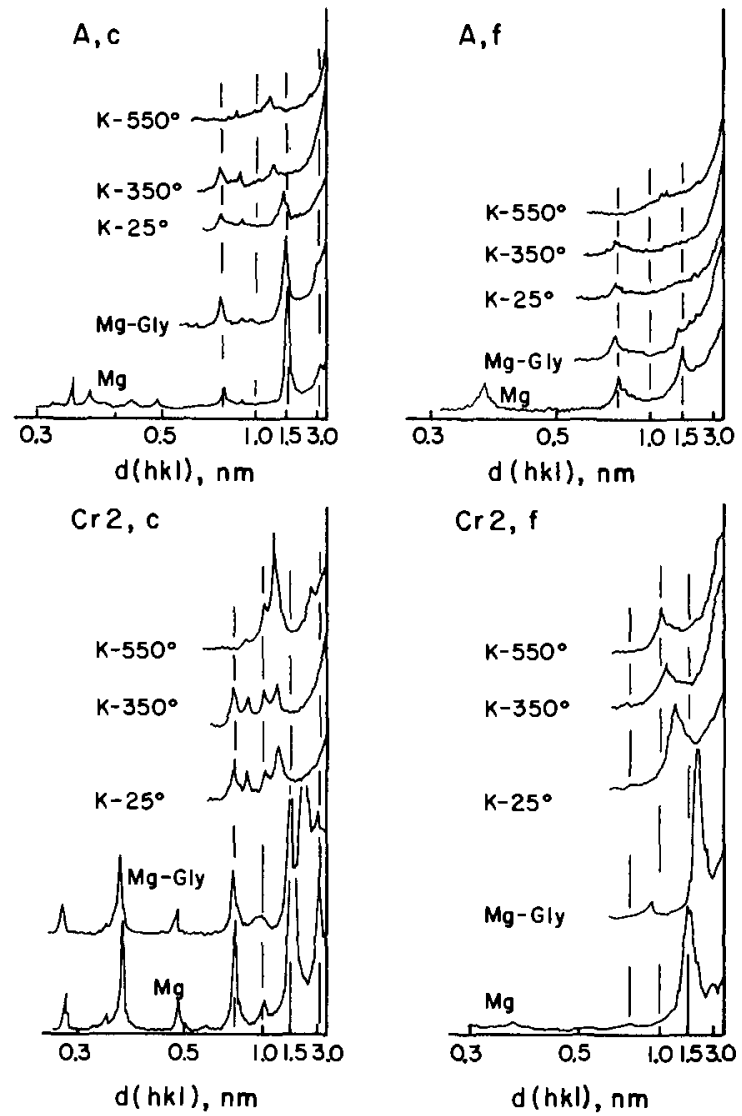

Fig. 3.-X-ray diffractograms of coarse and fine clay from the $A$ and Cr2 horizon of the Enon (metagabbro) profile. disorder required for the selective removal of the hydroxide sheet in the weathering of chlorite to vermiculite via interstratified intermediates (Jackson, 1968; Senkayi et al., 1981).

2) Quartz is the predominant mineral in the fine sand and medium silt fractions of the upper horizons (Table 4) and some quartz is also found in the coarse clay fractions in all but the $\mathrm{Cr} 2$ horizon. Quartz is the most resistant primary mineral in this soil profile.

3) Hornblende weathers, presumably to smectite, in all soil and saprolite horizons and is found mainly in the fine sand of the $\mathrm{Cr} 2$ horizon (Fig. 3). The presence of the hornblende in the medium silt fraction of the
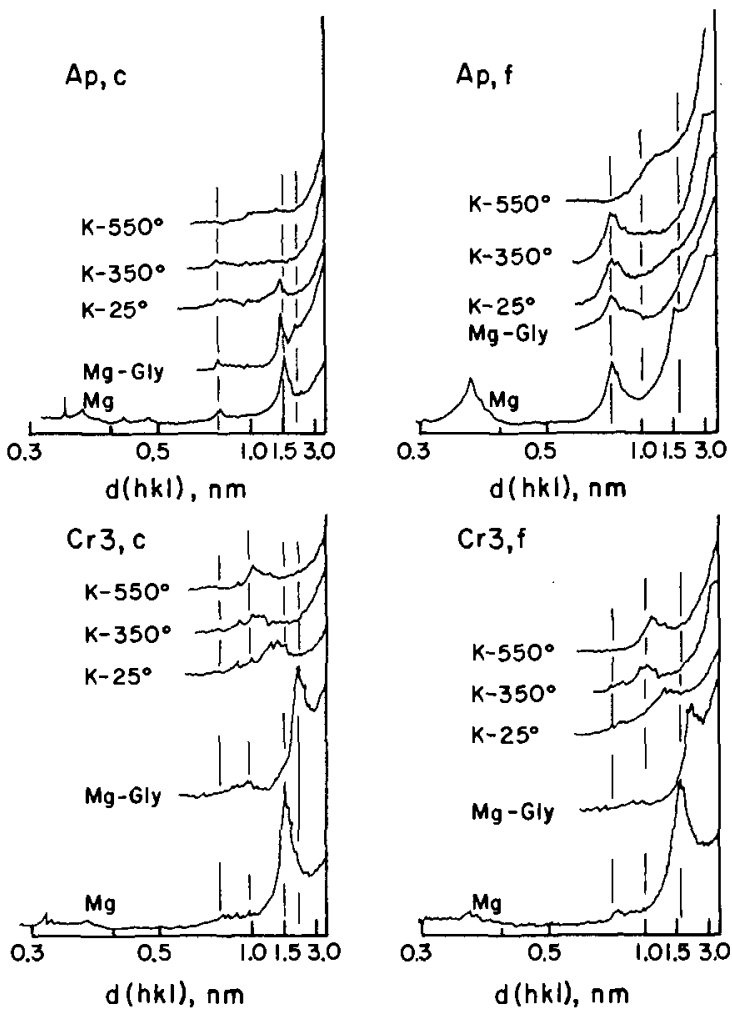

Fig. 4.-X-ray diffractograms of the coarse and fine clay from the Ap and Cr3 horizon of the Enon (gabbro) profile. 


\begin{tabular}{|c|c|c|c|c|}
\hline Horizon & Depth & $\begin{array}{c}\text { Fine } \\
(<0.2 \times \\
10^{-6} \mathrm{~m} ; \\
-\mathrm{Fe})\end{array}$ & $\begin{array}{c}\text { Coarse } \\
(2-0.2 \times \\
10^{-6} \mathrm{~m} ; \\
-\mathrm{Fe})\end{array}$ & $\begin{array}{c}\text { Total } \\
(<2 \times \\
10^{-6} \mathrm{~m} ; \\
+\mathrm{Fe})\end{array}$ \\
\hline & $10^{-2} \mathrm{~m}$ & $\longrightarrow$ & $-\%$ & \\
\hline \multicolumn{5}{|c|}{ Enon (metagabbro) profile } \\
\hline $\begin{array}{l}\mathrm{r} 1 \\
\mathrm{r} 2 \\
\mathrm{r} 3\end{array}$ & $\begin{array}{c}0-10 \\
10-20 \\
20-33 \\
33-51 \\
51-71 \\
71-81 \\
81-114 \\
114-147 \\
147-188\end{array}$ & $\begin{array}{r}31 \\
24 \\
44 \\
47 \\
48 \\
25 \\
12 \\
18 \\
9\end{array}$ & $\begin{array}{l}12 \\
19 \\
24 \\
37 \\
43 \\
35 \\
38 \\
30 \\
26\end{array}$ & $\begin{array}{l}16 \\
27 \\
39 \\
45 \\
48 \\
26 \\
32 \\
26 \\
20\end{array}$ \\
\hline \multicolumn{5}{|c|}{ Enon (gabbro) profile } \\
\hline r1 & $\begin{array}{c}0-18 \\
18-43 \\
43-64 \\
64-86 \\
86-135 \\
135-165 \\
165-203\end{array}$ & $\begin{array}{l}43 \\
44 \\
52 \\
36 \\
31 \\
24 \\
28\end{array}$ & $\begin{array}{l}19 \\
19 \\
13 \\
20 \\
18 \\
23 \\
20\end{array}$ & $\begin{array}{l}34 \\
36 \\
39 \\
30 \\
19 \\
18 \\
21\end{array}$ \\
\hline
\end{tabular}

A horizon is likely due to the addition of hornblende from weathering metagabbro boulders frequently present on the surface.

4) The smectite and vermiculite that weather from hornblende and from interstratified chloritevermiculite become increasingly hydroxy-interlayered from the $\mathrm{Cr} 2$ to the A horizon as evidenced by incomplete collapse to $1 \mathrm{~nm}$ after $\mathrm{K}$-saturation and heating to $550^{\circ} \mathrm{C}$. The fixation of $\mathrm{OH}-\mathrm{Al}$ polymers by vermiculite (Hsu and Bates, 1964; Rich, 1961) and montmorillonite (Barnhisel, 1966; Barnhisel and Rich, 1963; Shen and Rich, 1962) in the laboratory has been shown to reduce the specific surface, reduce the CEC, increase the stability to heat treatment, and decrease the minerals' ability to expand when glycol solvated. A change in the soil environment to a more acid pH (Table 3 ) or to a condition of increased silica leaching causes smectites to become unstable (Borchardt, 1977). Weathering proceeds by dissolution, by conversion to kaolinite (Altschuler et al., 1963), or more commonly, by polymerization of hydroxy-Al between expanding layers of smectites to form pedogenic chlorite (hydroxyinterlayered smectite or vermiculite) (Hsu, 1977).

5) Kaolinite is the single most abundant mineral in the clay fractions of the $\mathrm{Bt} 2$ and $\mathrm{Bt} \mathrm{l}$ horizons and decreases to $16 \%$ of the total clay fraction in the $A$ horizon (Table 5). This decrease of kaolinite in the A horizon coupled with an increase of hydroxy-interlayering of 2:1 minerals implies that hydroxy-interlayering increases the stability of smectite and vermiculite (Weed and Nelson, 1962). Kaolinite tends to become depleted in surface soil horizons in the coarse clay and silt fractions when weathering is advanced (Dixon, 1977).

6) The possible formation of smectite from ferromagnesian minerals and from chlorite intermediates implies two kinds of smectite: transformation smectite from chlorite and neogenetic smectite formed from ions supplied by other ferromagnesian minerals (Borchardt, 1977). Clay minerals may form via several dif-
Table 6. Surface areas and cation exchange capacities of nondeferrated clay fraction.

\begin{tabular}{|c|c|c|c|c|c|c|c|}
\hline $\begin{array}{l}\text { Hori- } \\
\text { zon }\end{array}$ & Depth & $\begin{array}{c}\text { EGME } \\
\text { (total) }\end{array}$ & $\begin{array}{c}\text { Single } \\
\text { point BET } \\
\text { (external) }\end{array}$ & $\begin{array}{c}\text { Internal } \\
\text { (total- } \\
\text { external) }\end{array}$ & $\begin{array}{r}\text { CEC (1) } \\
(\mathrm{pH} 4.0)\end{array}$ & $\begin{array}{l}\text { CEC (2) } \\
\text { (pH 7.0) }\end{array}$ & $(2)-(1)$ \\
\hline & $10^{-2} \mathrm{~m}$ & $\longrightarrow$ & $-\mathrm{m}^{2} \mathrm{~kg}^{-1} 10^{-}$ & - & $\longrightarrow \mathrm{cr}$ & $\mathrm{mol}(+) \mathrm{kg}$ & $g^{-1} \longrightarrow$ \\
\hline \multicolumn{8}{|c|}{ Enon (metagabbro) profile } \\
\hline A & $0-10$ & 236 & 66 & 170 & 22.8 & 31.8 & 9.0 \\
\hline $\mathbf{E}$ & $10-20$ & 223 & 96 & 127 & 32.4 & 38.7 & 6.3 \\
\hline $\mathrm{BE}$ & $20-33$ & 243 & 86 & 157 & 38.7 & 40.1 & 1.4 \\
\hline Bt1 & $33-51$ & 297 & 97 & 200 & 47.0 & 52.6 & 5.6 \\
\hline Bt2 & $51-71$ & 344 & 98 & 246 & 56.1 & 57.9 & 1.8 \\
\hline $\mathrm{BC}$ & $71-81$ & 369 & 79 & 290 & 62.9 & 64.5 & 1.6 \\
\hline Cr1 & $81-114$ & -- & 58 & -- & 79.0 & 81.0 & 2.0 \\
\hline $\mathrm{Cr} 2$ & $114-147$ & -- & 56 & - & 77.1 & 81.1 & 4.0 \\
\hline $\mathrm{Cr} 3$ & $147-188$ & 415 & 57 & 358 & 74.3 & 82.0 & 7.7 \\
\hline \multicolumn{8}{|c|}{ Enon (gabbro) profile } \\
\hline Ap & $0-18$ & 296 & 112 & 184 & 36.6 & 42.3 & 5.7 \\
\hline $\mathrm{Bt}$ & $18-43$ & 377 & 114 & 263 & 50.8 & 55.6 & 4.8 \\
\hline $\mathrm{BC}$ & $43-64$ & 365 & 112 & 253 & 45.6 & 57.8 & 12.2 \\
\hline C & $64-86$ & 454 & 113 & 341 & 58.8 & 65.0 & 6.2 \\
\hline Cr1 & $86-135$ & 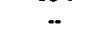 & 116 & $\cdots$ & 68.2 & 71.8 & 3.6 \\
\hline $\mathrm{Cr} 2$ & $135-165$ & -. & 111 & -- & 58.5 & 62.2 & 3.7 \\
\hline Cr3 & $165-203$ & 452 & 111 & 341 & 63.0 & 64.8 & 1.8 \\
\hline
\end{tabular}

ferent pathways (Fieldes and Swindale, 1954). If the primary minerals are not phyllosilicates, the formation of clay minerals involves release of cations, silica, and alumnia followed by recombination into phyllosilicate clays. The impeded drainage in this soil is conducive to this mechanism since the necessary ions are retained in the profile. If the primary rock contains phyllosilicate minerals, the alteration may take place in the solid state (Borchardt, 1977). Therefore, upon alteration of a rock containing both phyllosilicates (chlorite) and other silicate primary minerals (hornblende), it is possible to produce similar secondary products (smectite) from two different sources.

7) Surface area data (total, external, and internal) for the clay $\left(<2 \times 10^{-6} \mathrm{~m}\right)$ fraction (Table 6) show the total surface area to be greater than the external surface area in all horizons. Total surface area decreases from the $\mathrm{Cr} 3$ horizon to the A horizon. External surface area increases from the $\mathrm{Cr} 3$ horizon to the $\mathrm{Bt} 2$ horizon and then generally decreases toward the A horizon. This trend in external surface area is likely due to the maximum amount of fine clay in the Bt 2 horizon with decreasing fine clay content both above and below this horizon (Table 1). Internal surface area follows the same trend as total surface area and generally decreases from the $\mathrm{Cr} 3$ horizon to the A horizon. Increased hydroxy-interlayering of smectite and vermiculite could explain this measured decrease in interal surface area.

8) Cation exchange capacity (Table 6) of the clays $\left(<2 \times 10^{-6} \mathrm{~m}\right)$ decreases from the $\mathrm{Cr} 3$ horizon to the A horizon. This decrease is attributable to increased hydroxy-interlayering with proximity to the soil surface. Cation exchange capacity data for the total soil (Table 1) show a general increase from the $\mathrm{Cr} 3$ horizon to the $\mathrm{Bt} 2$ horizon reflecting an increased clay content in the Bt 2 horizon. Cation exchange capacity then decreases from the $\mathrm{Bt} 2$ horizon to the $\mathrm{E}$ horizon due to decreasing clay amounts, but increases in the A horizon due to a higher organic carbon content (Table 3). 


\section{Mineral Transformations in the Enon (gabbro) Profile}

A flow diagram (Fig. 2) showing proposed mineral transformations in the Enon (gabbro) soil-saprolite profile was constructed using XRD and DTA data. Several conclusions concerning mineral transformations in this profile can be drawn from the mineralogical compositions of the various particle size fractions (Table 4):

1. Hornblende weathers more rapidly than calcic plagioclase in the medium silt fractions in the upper soil horizons.

2. Kaolinite is more abundant in the fine clay than in the coarse clay fractions in all horizons (Table 5). Kaolinite content increases in the total clay fraction from the $\mathrm{Cr} 3$ horizon to the $\mathrm{BC}$ horizon, and then is relatively constant above. This suggests that kaolinite is being continuously supplied to the clay fraction by weathering of primary minerals, especially plagioclase, and by weathering of hydroxy-interlayered smectite or vermiculite. Little to no kaolinite is present in the silt and sand fractions, thus countering a particle break-down scenario.

3. Surface area data for clays (Table 6) show a decrease in total surface area from the $\mathrm{Cr} 3$ horizon to the Ap horizon. External surface area is relatively constant throughout all horizons, but is consistently higher than for the metagabbro profile. This does not seem to be consistent with the relative amounts of coarse and fine clay in the two profiles. The decrease in internal surface area from the $\mathrm{Cr} 3$ horizon to the Ap horizon suggests that smectite and vericulite destruction and/or smectite and vermiculite hydroxy-interlaying increase with proximity to the soil surface. The increase in hydroxy-interlayering is verified by XRD (data not shown).

4. Cation exchange capacity data for the clays (Table 6) show a general decrease from the $\mathrm{Cr} 3$ horizon to the Ap horizon. This CEC decrease can be explained in part by increased hydroxy-interlayering of smectite and vermiculite combined with increasing kaolinite contents in the epipedon. The CEC of the total soil increases from the $\mathrm{Cr} 3$ horizon to $\mathrm{Bt}$ horizon, then decreases in the Ap horizon (Table 3). The highest $C E C$ value occurs in the $B t$ horizon which corresponds to the zone of maximum clay content.

Very similar profiles result from the pedogenic and weathering processes on metagabbro and gabbro in the udic soil moisture and thermic soil temperature regimes of North Carolina. Although the profiles are similar enough for one series they are not identical. Regularly and randomly interstratified clays in the metagabbro-derived Enon profile are believed to result from the weathering of chlorite contained in the metagabbro. Interstratified clays are not present in the Enon profile derived from gabbro. The profile derived from the finer-grained metagabbro has greater silt content than does the profile developed from gabbro.

\section{REFERENCES}

1. Altschuler, Z.S., E.J. Dwornik, and H. Kramer. 1963. Transformation of montmorillonite to kaolinite during weathering. Science 141: 148-152.

2. American Geological Institute. 1976. Dictionary of Geologic Terms. Anchor Press/Doubleday. Garden City, NY.
3. Anderson, J.U. 1963. An improved pretreatment for mineralogical analysis of samples containing organic matter. 10 th Conf. Clays Clay Minerals 10:380-388.

4. Barnhisel, R.I. 1966. Changes in specific surface areas of clays treated with hydroxy-aluminum. Soil Sci. 107:126-130.

5. Barnhisel, R.I., and C.I. Rich. 1963. Gibbsite formation from aluminum interlayers in montmorillonite. Soil Sci. Soc. Am. Proc. 27:632-635.

6. Basham, I.R. 1974. Mineralogical changes associated with deep weathering of gabbro in Aberdeenshire. Clays Clay Minerals 10:189-202

7. Borchardt, G.A. 1977. Montmorillonite and other smectite minerals, pp. 293-330. In J.B. Dixon and S.B. Weed (ed.) Minerals in soil environments. Soil Science Society America, Madison, WI.

8. Buol, S.W., and D.M. Fadness. 1961. New method for impregnating fragile material for this sectioning. Soil Sci. Soc. Am. Proc. 25:253.

9. Buol. S.W and F.D. Hole 1961. Clay skin genesis in Wisconsin soils. Soil Sci. Soc. Am. Proc. 25:377-379.

10. Butler, J.R. 1953. The geochemistry and mineralogy of rock weathering: I. The lizard area, Cornwall. Geochim. Cosmochim. Acta 4:157-178.

11. Cady, J.G. 1950. Rock weathering and soil formation in the North Carolina Piedmont region. Soil Sci. Soc. Am. Proc. 15:337-342.

12. Carter, D.L., M.D. Heilman, and C.L. Gonzalez. 1965. Ethylene glycol monoethyl ether for determining surface area of silicate minerals. Soil Sci. 100:356-360.

13. Craig, D.C., and F.C. Loughnan. 1964. Chemical and mineralogical transformations accompanying the weathering of basic volcanic rocks from New South Wales. Aust. J. Soil Res. 2:218234.

14. DeConinck, F., G. Stoope, and R.K. Chatterjee. 1977. Weathering of chlorite in tropics. p.53-62. In K.T. Joseph (ed.) Conf. on Classification and Management of Tropical Soils, Kuala Lumpur, Malaysia, August 1977. Malaysian Society of Soil Science.

15. Dixon, J.B. 1977. Kaolinite and serpentine group minerals, pp. 357-404. In J.B. Dixon and S.B. Weed (ed.), Minerals in soil environments. Soil Science Society America, Madison, WI

16. Eswaran H. 1979. The alteration of plagioclases and augites under differing pedo-environmental conditions. J. Soil Sci. 20:547-555.

17. Fieldes, M. and L.D. Swindale. 1954. Chemical weathering of silicates in soil formation. N. Z. J. Sci. Technol. 36:140-154.

18. Gallaher, R.N., H.F. Perkins, and D. Radcliffe. 1973. Soil concretions: I. X-ray spectograph and electron microprobe analysis. Soil Sci. Soc Amer proc 37:465-469.

19. Glentworth, R. 1944. Studies on the soils developed on basic igneous rocks in central Aberdeenshire. Royal Soc. Edinburgh Trans. 61:149-170.

20. Hsu, P.H. 1977. Aluminum hydroxides and oxyhydroxides, pp. 99-144. In J.B. Dixon and S.B. Weed (eds.) Minerals in soil environments. Soil Science Society America, Madison, WI

21. Hsu, P.H., and T.F. Bates. 1964. Fixation of hydroxy-aluminum polymers by vermiculite. Soil Sci. Soc. Am. Proc. 28:763769.

22. Jackson, M.L. 1968. Weathering of primary and secondary minerals in soils. Trans. 9th Intl. Congress Soil Sci. 4:281-292.

23. Jackson, M.L. 1975. Soil chemical analysis-advanced course 2nd Ed., 10th Printing. Published by the author, Madison, WI

24. Johnson, L.J. 1964. Occurrence of regularly interstratified chlorite-vermiculite as a weathering product of chlorite in a soil. Am. Mineral. 49:556-572.

25. Kilmer, V.J., and L.T. Alexander. 1949. Methods of making mechanical analyses of soils. Soil Sci. 68:15-24.

26. Lee, W.F. 1955. The soils of North Carolina: their formation, identification and use. p. 70. North Carolina Agric. Expt. Sta. Tech. Bull. 115 .

27. Malcolm, R.L. 1968. Freeze-drying of organic matter, clays, and other earth materials. p. C211-C216. Paper 600-C, U.S. Geol. Survey Prof. Washington, DC

28. Marshall, C.E. 1977. The physical chemistry and mineralogy of soils. p. 81. Vol. II: Soils in place. J. Wiley and Sons, NY.

29. McCracken, R.J., S.B. Weed, and E.F. Goldston. 1964. Planosolic Piedmont soils of North Carolina: I. Morphology and composition. Soil Sci. 98:22-32.

30. Nettleton, W.D., K.W. Flach, and R. Brasher. 1969. Argillic horizons without clay skins. Soil Sci. Soc. Am. Proc. 33:121125.

31. Nyun, M.A., and S.B. McCaleb. 1955. The reddish brown lateritic soils of the North Carolina Piedmont region: Davidson and Hiwassee series. Soil Sci. 80:27-41.

32. Peech, M., R.L. Cowen, and J.H. Baker. 1962. A critical study 
of the $\mathrm{BaCl}_{2}$-triethanolamine and the ammonium acetate methods for determining the exchangeable hydrogen content of soils. Soil Sci. Soc. Am. Proc. 26:37-40.

33. Rich, C.I. 1961. Aluminum in interlayers of vermiculite. Soil Sci. Soc. Am. Proc. 24:26-32.

34. Senkayi, A.L., J.B. Dixon, and L.R. Hossner. 1981. Transformation of chlortie to smectite through regularly interstratified intermediates. Soil Sci. Soc. Am. J. 45:650-656.

35. Shen, M.J., and C.I. Rich. 1962. Aluminum fixation in montmorillonite. Soil Sci. Soc. Am. Proc. 26:33-36.

36. Soil Conservation Service. 1972. Soil survey laboratory methods and procedures for collecting soil samples. Soil Survey Investigations Report 1. SCS-USDA, U.S. Government Printing Office, Washington, DC.
37. Soil Survey Staff. 1975. Soil taxonomy. USDA Handb. 436. U. S. Government Printing Office, Washington, D.C.

38. Weed, S.B., and L.A. Nelson. 1962. Occurrence of chlorite-like intergrade clay minerals in Coastal Plain, Piedmont, and Mountain soils of North Carolina. Soil Sci. Soc. Am. Proc. 26:393398.

39. Wilson, M.J. 1966. The weathering of biotite in some Aberdeenshire soils. Mineral Mag. 35(276):1080-1093.

40. Wilson, M.J. 1970. A study of weathering in a soil derived from a biotite-hornblende rock: I. Weathering of biotite. Clay Minerals 8:291-303.

41. Wilson, M.J., and V.C. Farmer. 1970. A study of weathering in soil derived from biotite-hornblende rock: II. Weathering of hormblende. Clay Minerals 8:435-444. 